\title{
Analisis Peran Stakeholder Desa Wisata Carangsari, Kecamatan Petang, Kabupaten Badung
}

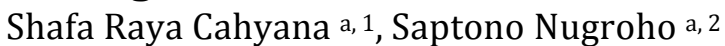

${ }^{1}$ shafarayacahyana98@gmail.com, ${ }^{2}$ saptono_nugroho@unud.ac.id

a Program Studi Sarjana Destinasi Pariwisata, Fakultas Pariwisata,Universitas Udayana, Jl. Dr. R. Goris No 7, Denpasar, Bali 80232 Indonesia

\begin{abstract}
Carangsari tourism Village is one of the tourist villages in Badung Regency, with various natural and cultural potentials. This study aims to determine the role of the three pillars of tourism in carrying out its right and responsibilitiestowards of Carangsari Tourism Village.The metode used in this study is a qualitative method with qualitative descriptive techniques understand the role of stakeholders in Carangsari Tourism Village, Petang District, Badung Regency. Used some sources of data including primary data and secondary data. The collection data technique, in this study, is using observation, interviews, library studies, and several interviewguidance instrument. Determination of informant in the study of the role of stakeholder in Carangsari Tourism Village used purposive sampling to obtain accurate data on the role of three tourism pillar actor on management in Carangsari Tourism Village, Petang District, Badung Regency. The results of this study obtained the active aspectf, status, right, and obligation Carangsari Tourism Village, Petang District, Badung Regency.
\end{abstract}

Keywords: Stakeholder, Role, Village Tourism, and Badung.

\section{PENDAHULUAN}

Pariwisata memiliki beragam jenis yang tersedia didalamnya, mulai dari pariwisata yang memerlukan kuantitas besar sampai kuantitas kecil. Tentu saja, disamping memerlukan kuantitas sebagai daya dukung, pariwisata juga harus ditunjang dengan kualitas wisatawan yang saling menguntungkan. Tren pariwisata milenial ternyata lebih akrab ke bagian kuantitas besar tetapi menghasilkan wisatawan yang kualitas rendah. Sayangnya, sampai saat ini praktik tersebut masih terus digencatkan oleh pemerintah pusat. Menurut Suidana (2017) Para ahli sudah memperkirakan bahwa pariwisata yang lebih mementingkan kuantitas dimasa mendatang akan merugikan lingkungan seperti pencemaran, kerusakan ekosistem yang ada serta pembangunan yang sangat banyak untuk menunjang praktik pariwisata massal. Target yang disiapkan pemerintah pusat sebesar 20 juta wisatawan yang datang ke Indonesia. Tentunya dalam hal ini, Pulau Bali akan berdampak akan target yang dicanangkan pemerintah tersebut. Ini mampu membuat kapasitas atau daya dukung akan semakin membesar lalu terjadi kebocoran atau yang sering disebut carying capacity.

Peran stakeholder sangat diperlukan Desa Wisata Carangsari karena dalam pengelolaan desa wisata sangat perlu pemangku kepentigan yang akan melaksanakan kewajibannya sesuai dengan jabatan maupun kedudukan individu maupun kelompok dalam status sosialnya di desa tersebut. Desa wisata sesungguhnya diprakarsai untuk mensejahterakan masyarakat desa dengan memanfaatkan potensi-potensi autentik yang dimiliki desa wisata Carangsari sebagai penumbuh ekonomi dari masyarakat itu sendiri agar terlihat lebih layak. Pengelolaan desa wisata yang baik akan menghasilkan output yang baik pula karena dalam pengimplementasian peran stakeholder ini harus mampu memajukan desa wisata ini yang sedang dalam tahap pengembangan. Stakeholder mampu memberikan kinerja pengelolaan dengan baik dengan kapasitas itu maka stakeholder mampu dikatakan komunitas yang memberi pengaruh baik dalam sistem sosial yang dibuat. Menariknya dengan memberikan peranan ini diharapkan mampu menjadikan seseorang merasa memiliki akan tanggung jawab atas jabatan yang dimilikinya saat ini.

Kabupaten Badung sampai saat ini masih eksis dengan pariwisata yang mampu mendorong pendapatan daerah, pusat dalam pariwisata berada di Kuta, Canggu, Seminyak, dan lainnya. Sayangnya, dipusat masifnya pertumbuhan ekonomi disektor pariwisata. Kabupaten Badung terjun kedalam jurang pariwisata massal yang sampai hari ini masih terimplementasi. Dengan fenomena seperti ini pemerintah mulai mencari solusi untuk ketimpangan 
ekonomi yang terjadi di Kabupaten Badung dalam memetik buah pariwisata yang sampai saat ini dimimpi-mimpikan oleh masyarakat. Solusi yang didapatkan oleh masyarakat dalam menghadapi ketimpangan ekonomi pariwisata yaitu dengan membuat desa wisata yang berlokasi disalah satu bagian utara Kabupaten Badung.

Kecamatan petang merupakan tempat yang menghimpun beberapa desa didalam administrasinya. sebanyak lima desa wisata tercetus atas solusi untuk menyelesaikan masalah yang terjadi di Kabupaten Badung. Dari sekian desa wisata yang telah menjadi ikonik di wilayah utara, ternyata tidak sebaik jalan yang diharapkan. Hanya dua desa wisata yang mampu berjalan dan memanfaatkan potensi yang dimiliki desa tersebut untuk dijadikan atraksi wisata. Sementara itu ketiga desa yang masih belum mampu mengenali jati dirinya untuk mengelola potensi dengan baik salah satunya yaitu Desa Wisata Carangsari (Suryawan, 2016).

Desa Wisata Carangsari merupakan desa wisata yang mengembangkan wisata budaya sebagai produk utamanya. Memiliki keunikan tentang sejarah pahlawan yang membela rakyat Bali dari penjajah kolonial Belanda menciptakan suatu daya tarik yang ingin diketahui oleh wisatawan. Pahlawan rakyat Bali yang berasal dari Desa Carangsari adalah I Gusti Ngurah Rai, puri peninggalan beliau saat ini telah diwarisakan kepada keturunannya. Desa Wisata Carangsari sudah berkembang menjadi desa wisata, beberapa hari belakangan ini mencuat tentang tempat melukat yang sering dikunjungi wisatawan maupun pelancong. Namun sayangnya, desa ini belum secara optimal dalam memanfaatkan sumber daya yang ada sehingga belum mampu bangkit dalam menjalankan keggiatan pariwisata di desa tersebut. dengan sumber daya yang ada diharapkan mampu menjadi suatu potensi yang dapat dikembangkan kembali dalam produk-produk wisata yang menjadi ketertarikan wisatawan untuk berkunjung ke Desa Wisata Carangsari.

Dengan merujuk fenomena yang telah dijabarkan, melalui perkembangan desa wisata yang sedang mulai digencatkan dalam beberapa tahun belakangan ini, diharapkan desa wisata bukan lagi menjadi label semata dan Desa Wisata Carangsari mampu bangkit dalam menjalankan keberlangsungan sektor pariwisata yang dianggap mampu mensejahterakan masyarakat lokal juga menjadi suatu penggerak dalam mangkraknya desa wisata lain di Kabupaten Badung. Tujuan dari penelitian ini yaitu untuk mengetahui sejauh mana peran pemangku kepentingan yang ada di Desa Wisata Carangsari. Secara manfaat ditujukan kepada pemerintah, pengusaha lokal, dan juga masyarakat lokal sehingga mampu dijadikan acuan bagi pemangku kepentingan dalam melaksanakan konsep peran yang sesuai dengan kedudukan masing-masing status sosial.

Adapun perbedaan posisi penelitian ini dengan penelitian sebelumnya akan dijabarkan sebagai berikut:

- Penelitian yang menjadi rujukan peneliti yang pertama adalah memahami kembali eksistensi stakeholder yang ada di Desa Wisata Baha, penelitian yang melihat aktivitas pariwisata yang sedang berjalan serta pola koordinasi antara pemangku kepentingan yang menjadi otorias utama dalam sektor wisata tersebut. Stakeholder di desa itu cenderung individualitas serta memeintangkan haknya saja tanpa diseimbangkan dengan kewajibannya masing-masing. Dapat dilihat dalam penelitian sebelumnya, belum adanya persepsi yang sama antara stakeholdetr di Desa Wisata Baha. Persamaannya terletak pada konsep stakeholder yang menjadi rujukan utamanya serta metode yang digunakan, sedangkan perbedaanyaa terletak pada lokasi penelitian yang dipakai.

- Acuan kedua terdapat pada penelitian tentang mengupayakan atas pengembangan Desa Wisata Carangsari, penelitian ini membahas akan potensi yang ada di desa tersebut dan juga mencoiba mengupayakan tentang bagaimana tahap pengembangan yang dapat menjadi salah satu terobosan utama untuk membuat desa wisata ini bergerak maju. Melalui upaya tersebut 
diharapkan mampu menjadi salah satu titik mempersatukan pihak yang terdapat dalam desa wisata tersebut. Persamaan dalam penelitian ini terdapat pada lokasi penelitian yaitu sama-sama memakai Desa Wisata Carangsari sedangkan pada perbedaannya terletak pada fokus penelitian yang sebelumnya meneliti tentang upaya pengembangan sedangkan penelitian ini memakai fokus peran stakeholder. Keunikan dari penelitian ini dilihat dari topik penelitian yang menggunakan analisis peran dari setiap pemangku kepentingan. Melihat seluruh elit dalam memaknai fungsi tugasnya dalam menjalankan kedudukan sosial.

Rujukan konsep yang pertama yaitu Konsep Desa Wisata Carangsari, Desa wisata merupakan suatu jalan pariwisata alternative yang berpegang pada bentuk-bentuk positif dalam setiap kegiatan serta menyumbang pada daya dukung sosial, ekonomi, maupun budaya di daerah perdesaan. Ini juga dukung oleh pernyataan bahwa wisatawan yang akan tinggal di desa wisata merasa dekat dengan masyarakat lokal yang memiliki kuantitas kecil dan melakukan kehidupan tradisional bersama masyarakat lokal di lingkungan setempat. Konsep ini nantinya digunakan dalam melaksakan pengotakan fokus dalam melakukan penelitian di desa wisata.

Rujukan konsep yang kedua yaitu konsep peran aktor pariwisata, menggunakan konsep peran untuk mengetahui sejauh mana pemangku kepentingan atau elite yang ada di Desa Wisata Carangsari melaksanakan peran sebagai mana mestinya, apabila orang mempunyai aspek atif yang ditunjang langsung oleh status sosial yang berlaku serta melaksakanan tanggung jawabnya, Mendapatkan haknya serta melaksakan kewajiban sesuai status sosialnya maka orang tersebut dianggap sudah melaksakan peranan. Peran sebagai pemimpin digunakan di Desa WIsata Carangsari untuk mengidentifikasi bagaimana peran pemimpin dalam memangku kepentingan dalam mengelola desa wisata ini.
- Konsep ketiga yang dirujuk yaitu Konsep 3 pilar pariwisata sebagai identifikasi dalam kegiatan pariwisata yang dihimpun oleh aktor-aktor yang berkapasitas berbeda dalam pelaksanaan tugasnya, aktor desa wisata carangsari dibagi menjadi tiga yang utama ada pemerintah sebagai lingkup administratif, swasta atau pengusaha sebagai penunjang perekonomian yang turun langsung melayani wisatawan, serta masyarakat lokal yang dihelatkan menjadi pencipta kegiatan itu sendiri, pemilik modal sumber daya yang mumpuni dalam lahan wisata tersebut. Konsep ini digunakan untuk memetakan pemangku kepentingan sesuai dengan modal yang dimiliki serta mampu menganalisis bagaimana kedudukan ini memberikan sepenuhnya tanggung jawab kepada aktor pariwisata di Desa Wisata Carangsari.

\section{METODE PENELITIAN}

Penelitian ini berlokasi di Desa Wisata Wisata Carangsari yang merupakan desa wisata yang letaknya paling awal di Kecamatan Petang, Kabupaten Badung. Desa wisata ini juga sedang mengembangkan sektor pertanian dalam pengembangannya karena karakteristik tersebutlah yang mampu dikelola oleh masyarakat untuk menarik minat wisatawan yang berkunjung. Desa ini lokasinya yang berhimpitan langsung dengan sungai ayung dengan pemandangan yang indah juga aktivitas kepariwisataan seperti rafting pada gambar 1.1 yang sangat digemari oleh wisatawan.

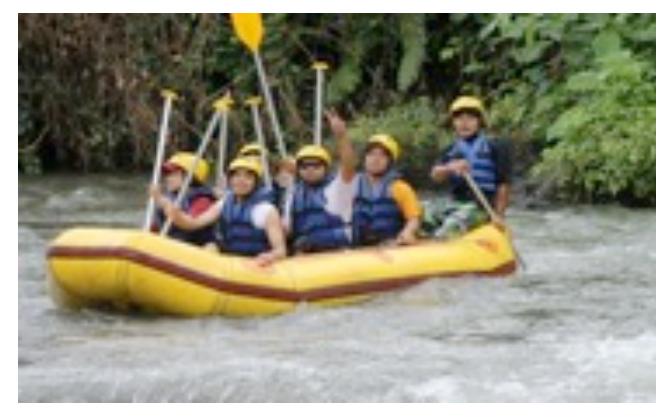

Gambar 1.1 Rafting di Sungai Ayung

Sumber: Peneliti, 2019

Jenis data dalam penelitian ini menggunakan data kualitatif untuk melaksanakan pembedahan data secara 
naratif. Data kuantitatif yang digunakan sebagai membedah data penunjang yang berbentuk angka maupun numerik dalam pengkajiannya penelitian di Desa Wisata Carangsari.

Teknik pengumpulan data dapat dilakukan dalam penelitian ini yaitu menggunakan teknik observasi dengan melihat fenomena yang ada dilapangan. Kemudian peneliti melakukan wawancara dengan tanya jawab bersama informan agar mendapat jawaban yang tidak terduga untuk informasi tambahan.

Sumber data yang digunakan dalam penelitian peran stakeholkder ini adalah data primer untuk mencari data yang ada di tempat peniitian langsung dan data sekunder untuk mencari data sebagai penunjang diluar data utama untuk memperkuat fakta di tempat penelitian.

Teknik analisis data dalam penelitian ini menggunakan teknik analisis kualitatif dengan menganalisis proses sosial yang berlangsung bertajuk pada fenomenafenomena yang ada di Desa Wisata Carangsari.

\section{HASIL DAN PEMBAHASAN}

Berdasarkan hasil penelitian dilapangan dapat diperoleh hasil berupa matriks mengenai peran stakeholder Desa Wisata Carangsari, Kecamatan Petang, Kabupaten Badung. Penelitian ini berlokasi di Desa Wisata Carangsari yang merupakan desa wisata yang letaknya paling awal di Kecamatan Petang, Kabupaten Badung. Desa wisata ini juga sedang mengembangkan sektor pertanian dalam pengembangannya karena karakteristik yang mampu dikelola oleh masyarakat untuk menarik minat wisatawan yang berkunjung. Desa ini berlokasi yang berhimpitan langsung dengan sungai ayung.

\section{A. Peran Pemerintah Desa Carangsari}

Pemerintah yang dalam hal ini yang dijadikan informan yaitu Kepala Desa Carangsari, dengan kriteria mengetahui tentang kegiatan pariwisata yang berada di desa ini dan juga berada dala pusaran stakeholder. Kepala desa juga memiliki semangat dalam menjalankan pariwisata, karena sektor pariwisata sangat diminati oleh masyarakat yang mengetahui benar bahwa sektor ini mampu mensejahterakan masyarakat dan juga melibatkan masyarakat dalam setiap pengelolaan yang ada di Desa Carangsari. Perekonomian masyarakat yang sebelumnya menengah kebawah diyakini akan mampu menambah sedikit kenaikan apabila mengembangkan desa wisata. Sesuai dengan kesadaran masyarakat yang telah mampu menjadikan Desa Carangsari menjadi desa wisata merupakan suatu langkah maju yang didapatkan oleh pemerintah desa dalam menggerakan masyarakat untuk ikut bersama-sama memajukan desa ini. Tahapan pada desa wisata ini berada di posisi pengembangan, segala upaya perencanaan dan juga memperbaiki sistem kelola desa yang nantinya akan adanya pengawasan langsung kepada organisasi yang menaungi desa wisata tersebut. Perencanaan semua hal yang terkait pariwisata diharapkan mampu rampung dalam kurun waktu satu tahun. Pada tahun 2020 Desa Wisata Carangsari harus sudah siap dalam menerima wisatawan dalam segi atraksi wisata sampai pada sumber daya manusia yang sudah professional. Atraksi wisata yang terdapat di Desa Wisata Carangsari yaitu pembangunan dan juga pembuatan home industry harus melakukan perizinan kepada kepala desa dan disepakati dengan adanya peraturan desa sebagai syarat untuk melakukan usaha.

Pemerintah memiliki aspek aktif sebagai regulator sebagai pembuat aturan-aturan maupun sangsi serta gerakan-gerakan yang mampu mengajak masyarakat untuk ikut mematuhi aturan yang telah dibuat. Peraturan yang telah diterapkan dalam membangun desa carangsari yang siap akan sektor pariwisata sebagaimana mestinya dalam penerapannya telah terkoordinasi dengan baik. Aspek aktif yang disematkan kepada pemerintah selanjutnya adalah sebagai fasilitator dalam menjajaki informasi terkait dengan kepariwisataan yang 
berlangsung di desa ini. Fasilitator yang dalam peran pemerintah juga dikaitkan dengan sebagai posisi tengah untuk menjadi aktor yang mampu menangani segala wacana maupun tindakan masyarakat yang masih belum terkoordinasi dengan baik, Kepala Desa Carangsari juga sering melakukan sosialisasi terhadap pariwisata bersama dengan pokdarwis kepada masyarakat yang diselipkan dalam paruman banjar yang sering dilakukan, dalam membahas isu-isu tertentu di sepuluh banjar di Desa Carangsari. Sosialisasi ini masih terus dilakukan berjenjang agar masyarakat tidak terkejut apabila banyak wisatawan yang nantinya datang ke desa ini. Pemerintah desa dalam hal ini juga masih sering melakukan upaya penguatan sumber daya manusia dalam berbagai program yang ditindak lanjuti dari kabupaten maupun program yang diciptakan di desa itu sendiri. Hak yang diterima dalam melaksakan perannya adalah mendapatkan modal simbolik yang memiliki citra desa wisata dan juga mendapatkan subsidi dari pelaksanaan pariwisata di Desa Wisata Carangsari. Namun, untuk restribusi yang masuk ke desa sampai saat ini belum terlaksana dengan baik karena masih ditahap pengembangan dan belum berjalan dengan optimal dalam kunjungan wisatawan.

\section{B. Peran Pengusaha Lokal di Desa Carangsari}

Pengusaha pariwisata di Desa Wisata Carangsari saat ini masih mengandalkan masyarakat lokal, sebagai pengusaha pasti memiliki modal dibidang ekonomi untuk memajukan usahanya hingga mampu diterima oleh wisatawan. Banyak masyarakat yang membuka usaha kecil menengah untuk sama-sama bersaing disektor pariwisata. Dengan mengandalkan potensi alam yang ada seperti aliran sungai ayung, seseorang yang memiliki modal ekonomi membuka usaha arung jeram. Sampai saat ini ada delapan usaha arung jeram yang terdaftar di Desa Carangsari. Desa ini belum mendapat dukungan dari pengusaha diluar masyarakat itu sendiri karena dalam keterangannya masih belum siap dalam melaksanakan syarat dan ketentuan dari keduabelah pihak jika nantinya saling bekerja sama. Hal ini yang menyebabkan desa wisata ini belum sepenuhnya dimasuki peran pengusaha sebagai investor atau pendonatur yang mampu secara penuh mendanai faktor-faktor yang menunjang pariwisata. Dengan tidak melibatkan investor dari luar desa juga menjadi dampak positif dari keberlangsungan pariwisata karena meredam kecemburuan akan adanya investor yang masuk ke beberapa wilayah saja.

Hak yang dapat diterima oleh pengusaha lokal adalah mendapatkan jaminan kepuasan dalam melaksanakan usahanya, mampu bersaing secara sehat tanpa adanya konflik dagang yang terlihat manifest, dan juga dapat ikut secara aktif dalam kesempatan menikmati sektor pariwisata di desa wisata tersebut. kewajiban yang harus dilaksanakan yaitu bisa memberdayakan masyarakat sekitar untuk turut serta dalam usaha tersebut, juga memberikan retribusi terhadap pemerintah dan masyarakat dari penjualan produk yang ditawarkan, memberikan inovasi program yang dapat mempromosikan Desa Carangsari agar lebih dikenal oleh wisatawan. Kewajiban sebagai seorang pengusaha masih belum maksimal karena belum terjalinnya retribusi kepada pemerintah dan juga masyarakat serta belum adanya inovasi program yang dapat diterapkan oleh pengusaha lokal. Ini menjadikan peran yang berlangsung belum cukup optimal dalam penerapannya.

\section{Peran Masyarakat Lokal Desa Carangsari}

Masyarakat lokal dalam hal ini mempunyai peran yang sangat penting, dalam konsep tentang pilar pariwisata mencantumkan bahwa penduduk sekitar yang memiliki sumber daya alam dan sumber daya manusia yang mampu menunjang keberlangsungan sektor ini. Hal serupa tercantum pada aspek aktif dari masyarakat lokal yaitu sebagai partisipasi. Partisipasi masyarakat 
sangat dibutuhkan apabila telah mencapai tingkatan yang aktif dalam pelaksanaannya. Masyarakat sekitar sudah diarahkan untuk mengikuti program-program yang disepakati untuk menjadikan desa ini ramah akan wisatawan yang berkunjung. Masyarakat juga mempunyai peranan penting dalam setiap tahapan-tahapan dalam pelaksanaan kepariwisataan yang bisa mengawasi akan sepak terjang sektor untuk keberlangsungan kesejahteraan masyarakat sekitar. Dampak langsung yang disebabkan oleh sektor ini tertuju pada masyarakat sekitar. Maka dari itu, upaya dalam pengambilan keputusan dalam setiap pengembangan pariwisata diharpakan selalu menyertakan masyarakat sekitar untuk mencapai musyawarah mufakat. Desa wisata carangsari sudah melakukan penyertaan masyarakat lokal dalam mengelola pariwisata dengan membentuk kelompok sadar wisata (Pokdarwis) Carangsari yang diharapkan mampu menjadi penggerak dalam pengelolaan desa wisata ini. Kewajiban untuk membentuk program penunjang pemberdayaan masyarakat ke arah pariwisata sudah mulai digencatkan, dengan sasaran generasi muda beserta ibu-ibu PKK dalam upaya melakukan pelayanan terhadap wisatawan, berkoordinasi dengan lembaga lainnya untuk masalah keamanan dan kenyamanan di desa ini serta mendukung program kebersihan (Gertak) untuk melaksakannya di desa. Sebagai masyarakat lokal yang memiliki lahan produktif untuk pariwisata mendapatkan haknya seperti pemberdayaan, mendapatkan hasil (ekonomi) dari kegiatan pariwisata, dan dapat terlibat langsung sebagai pengusaha maupun pegawai di industri rumahan. Hal ini juga merupaakan sesuatu yang menjadi tantangan tersendiri dalam pelaksanaan peran, kualitas stakeholder yang mampu bisa sama-sama berjalan seimbang sesuai dengan aspek-aspek yang telah diterangkan. Adapun penjelasan terkait peran stakeholder dijelaskan lebih singkat melalui matriks 3.1, berikut penjelasannya:

Matriks 3.1 Analisis Peran Stakeholder Desa Wisata Carangsari

\begin{tabular}{|c|c|c|c|}
\hline stakeholder & Pemerintah & Pengusaha & $\begin{array}{l}\text { Masyarakat } \\
\text { lokal }\end{array}$ \\
\hline Aspek aktif & $\begin{array}{l}\text { Fasilitator/ } \\
\text { Regulator }\end{array}$ & Investor & Partisipator \\
\hline Status & $\begin{array}{l}\text { Kepala Desa } \\
\text { Carangsari }\end{array}$ & $\begin{array}{l}\text { Pengusaha } \\
\text { lokal yang } \\
\text { memiliki } \\
\text { usaha } \\
\text { aktifitas } \\
\text { pariwisata }\end{array}$ & $\begin{array}{l}\text { Masyarakat } \\
\text { lokal Desa } \\
\text { Carangsari }\end{array}$ \\
\hline Hak & $\begin{array}{l}\text { Mendapatkan } \\
\text { retribusi dari } \\
\text { aktivitas } \\
\text { pariwisata }\end{array}$ & $\begin{array}{l}\text { Dapat } \\
\text { menciptakan } \\
\text { usaha yang } \\
\text { menyangkut } \\
\text { sektor } \\
\text { pariwisata } \\
\text { dan dapat } \\
\text { didukung } \\
\text { oleh } \\
\text { masyarakat } \\
\text { maupun } \\
\text { pemerintah } \\
\text { desa }\end{array}$ & $\begin{array}{l}\text { Melibatkan } \\
\text { masyarakat } \\
\text { untuk setiap } \\
\text { pengambilan } \\
\text { keputusan } \\
\text { dan hak } \\
\text { untuk } \\
\text { membuka } \\
\text { usaha di } \\
\text { sektor } \\
\text { pariwisata }\end{array}$ \\
\hline Kewajiban & $\begin{array}{l}\text { Membuat } \\
\text { peraturan } \\
\text { desa terkait } \\
\text { pariwisata, } \\
\text { memfasilitasi } \\
\text { segala bentuk } \\
\text { informasi, } \\
\text { serta } \\
\text { menindaklanj } \\
\text { uti program- } \\
\text { program dari } \\
\text { pemerintah } \\
\text { kabupaten. }\end{array}$ & $\begin{array}{l}\text { Memberikan } \\
\text { restribusi } \\
\text { yang telah } \\
\text { disepakati } \\
\text { dengan } \\
\text { pemerintah } \\
\text { desa maupun } \\
\text { masyarakat, } \\
\text { memberdaya } \\
\text { kan } \\
\text { masyarakat } \\
\text { untuk ikut } \\
\text { serta dalam } \\
\text { usaha } \\
\text { pariwisata } \\
\text { yang } \\
\text { diciptakan }\end{array}$ & $\begin{array}{l}\text { Memberikan } \\
\text { kenyamanan } \\
\text { dan } \\
\text { keamanan } \\
\text { bagi } \\
\text { wisatawan } \\
\text { dan } \\
\text { mendukung } \\
\text { segala } \\
\text { kegiatan } \\
\text { pariwisata }\end{array}$ \\
\hline
\end{tabular}

Sumber, Penelitian, 2019

Peran yan telah dilaksanakan dalam matriks 1.1 merupakan gambaran yang jelas, bahwa sudah cukup baik dari setiap elemen stakeholder yang mampu berjalan sesuai dengan tanggung jawab. Ini juga menandakan bahwa Desa Wisata Carangsari sudah siap dalam menerima wisatawan untuk datang ke desa ini. Semua program yang telah terlaksana juga sudah mampu untuk menggerakkan masyarakat untuk terlibat aktif dalam setiap program yang direncanakan dari pemerintah daerah turun sampai ke pemerintah desa. 
Pemerintah desa dalam hal menjalankan tugas untuk membuat regulasi dibantu dengan aspirasi masyarakat yang ingin secara langsung berhadapan dengan pariwisata. Masyarakat sekitar masih menunggu sejauh mana kelanjutan dari label desa wisata ini hingga mampu memberikan peluang kerja sampingan terhadap masyarakat lokal. Pemerintah desa juga mengupayakan dengan menjadi sebagai fasilitator untuk masuk ke segala lini masyarakat agar informasi terhadap pariwisata tidak hanya dapat dimengerti secara segelintir manusia saja tetapi mampu secara menyeluruh dan diharapkan dapat memberikan gambaran tentang dampak positif maupun negatif yang perlu terbuka untuk diketahui oleh masyarakat.

Mendapatkan retribusi yang masuk ke desa juga akan diperuntukan oleh masyarakat desa, saat ini segenap masyarakat juga organisasi yang menjadi garda terdepan dalam wadah pariwisata sedang menunggu cairnya dana yang dapat membangun pariwisata di Desa Wisata Carangsari, nantinya dana yang didapatkan untuk membangun fasilitas fisik dan juga mamfasilitasi program yang menunjang pariwisata di desa tersebut. Hal pendanaan tersebut merupakan sesuatu yang perlu diperhitungkan dalam pengembangan desa wisata.

Pengusaha lokal yang ada di Desa Wisata Carangsari terlihat pada matriks 3.1 belumn dapat membagi keuntungan secara persentase terhadap pemerintah desa untuk membantu program desa wisata, pengusaha lokal juga menjadi penyumbang wisatawan untuk melihat lingkungan yang asri di Desa Wisata Carangsari. Masyarakat lokal juga diharapkan mampu saling mendukung terhadap pengusaha lokal dalam menjual hasil olahan dari sumber daya alam yang dapat dijadikan sebagai cendera mata sebagai oleh-oleh dari desa. Untuk bisa menunjang hal tersebut diharapkan juga pihak pengusaha lokal saling bersinergi dan tidak hanya mementingkan terhadap usahanya sendiri tanpa membantu masyarakat agar siap dalam menjamu pariwisata.

Masyarakat lokal menjadi salah satu tonggak sentral dalam melaksanakan pariwisata yang akan berkembang di desanya. Masyarakat di Desa Carangsari sudah setuju dengan adanya label desa wisata agar Puri Carangsari juga dikenal oleh masyarakat secara luas karena memiliki sejarah yang penting untuk Pulau Bali dalam perang Puputan Margarana. Dengan keberadaan Puri Carangsari ini masyarakat juga merasa diuntungkan karena mampu menjadi daya tarik wisata yang dapat dikunjungi langsung oleh wisatawan lokal maupun mancanegara. Masyarakat juga sudah merancang jalur-jalur trekking dan cycling agar wisatawan dapat melihat alam Desa Carangsari yang masih terjaga dan asri.

Kewajiban dari masing-masing stakeholder seharusnya bisa dilaksanakan dengan baik, terpampang jelas dalam penelitian ini dalam matriks 3.1 yang menjelaskan secara lengkap tentang upaya yang dapat dilakukan oleh masing-masing stakeholder dalam melakukan pengembangan maupun mengelola Desa Wisata Carangsari yang masuk dalam bagian desa wisata di Kabupaten Badung. Kewajiban yang telah dilaksakan kedepannya diharapkan mampu untuk menuntaskan program yang telah disinyalir untuk meningkatkan kualitas masyarakat desa maupun untuk mensejahterakan masyarakat lokal, menunjuk terhadap matriks 3.1 yang menyatakan program yang digencatkan nantinya diharapkan agar daopat menjadi sesuatu respoin yang nantinya masyarakat merasakan menerima ilmu dari program tersebut.

Setelah melaksanakan kewajiban maka stakeholder dapat mendapatkan hak yang sesuai dengan kinerja dari pengembangan desa wisata ini. Matriks 3.1 telah mengungkapkan beberapa hak yang nantinya didapatkan oleh masingmasing elemen tanpa mengambil hak dari elemen lainnya agar menjadi lebih stabil dan terorgansir lebih baik, adapun pengusaha lokal mendapatkan hak agar diberi ruang berusaha dan mendapatkan dukungan yang baik dari segala lapisan masyarakat maupun pemerintah serta hak dari pemerintah yaitu dapat mendapatkan retribusi mengenai pengelolaan desa wisata dalam lingkup aktivitas kepariwisataan.

Hak dari masyarakat agar mendapatkan perlibatan atas pengembangan maupun pembangunan pariwisata agar masyarakat dapat memberikan solusi maupun mengajukan aspirasi karena masyarakatlah yang memiliki sumber daya yang dipergunakan dalam aktivitas pariwisata, masyarakat harus selalu dilibatkan agar mampu memberikan masukan atau ide-ide yang membangun tanpa menutup keran aspirasi tersebut. pelibatan terhadap masyarakat harus 
sesuai dengan apa yang diaspirasikan karena masyarakat lokal yang memiliki wewenang terhadap potensi-potensi yang ada di desa wisata itu. Jangan sampai adanya overlapping peran yang nantinya bukan menjadi sinergi malah dapat kearah konflik yang tak terhindarkan karena adanya salah satu stakeholder yang tidak puas ataupun merasa selalu terasingi dalam pengembangan pariwisata di Desa Wisata Carangsari. Jika konflik tak bisa terhindarkan koordinasi maupun pengelolaan desa wisata tidak akan berjalan seimbang dengan apa yang diharapkan oleh seluruh elemen stakeholder, kedepannya pariwisata bukan menjadi sebagai pensejahera masyarakat tetapi malah memecah belah desa tersebut.

\section{PENUTUP}

Kesimpulan yang dapat ditarik pada penelitian hasil dari analisis peranan stakeholder Desa Wisarta Carangsari ini tersimpulkan bahwa desa ini memiliki tiga pilar pariwisata yang aktif dalam melaksakan keberlangsungan pariwisata, dengan adanya desa wisata masyarakat yakin keadaan ekonominya akan beranjak naik dari sebelumnya

Peran dari berbagai pilar yaitu pemerintah desa carangsari sudah melakukan program turunan dari pemerintah daerah yang menjadi salah satu aspek dalam memajukan pariwisata. Pengusaha lokal yang dinilai sudah menjalankan perannya dalam mengembangkan desa wisata dengan menciptakan usaha yang nantinya bisa menjadi salah satu promosi untuk ketertarikan wisatawan datang ke desa carangsari. Masyarakat lokal telah diajak untuk mengambil keputusan dan mendapatkan hak untuk menerima ekonomi secara langsung dari kegiatan pariwisata. Kurang terjalinnya komunikasi dan koordinasi yang dapat menjadikan antara pilar pariwisata menjadi satu persepsi dalam mengembangkan desa wisata ini.

Adapun saran yang dapat diberikan terkait dengan analisis peran stakeholder adalah untuk Pemerintah yaitu selalu dapat mempromosikan desa wisata carangsari ini agar terkenal lebih luas di kalangan wisatawan lokal juga dapat lebih membuka diri terhadap investor luar yang masuk untuk memajukan Desa Wisata Carangsari agar lingkupnya lebih luas, untuk pengusaha diharapkan mampu menciptakan suatu produk baru yang dapat memikat wisatawan untuk mengunjungi desa ini, serta untuk masyarakat lokal agar lebih siap untuk menjamu wisatawan yang hadir dan diharapkan juga mampu berinteraksi langsung terhadap wisatawan.

\section{DAFTAR PUSTAKA}

Anom, I. P, dkk. 2016. Perkembangan dan Pengembangan Desa Wisata. Bandung: Herya Media.

Bungin, Burhan. 2007. Penelitian Kualitatif Komunikasi, Ekonomi Kebijakan Publik dan Ilmu Sosial Lainya. Jakarta: Prenada Media Group.

Haryanti, L. dan S. Nugroho. 2018. Sinergi Stakeholder Dalaam Mewujudkan Aktivitas Pariwisata Di Desa Wisata Baha, Kecamatan Mengwi, Kabupaten Badung. Jurnal Destinasi Pariwisata p-ISSN: 2338-8811.

Julyantara, I. P. W. E. 2018. Upaya Pengembangan Desa Wisata Carangsari, Kabupaten Badung. Skripsi. Universitas Udayana.

Kusmayadi dan E. Sugiarto. 2000. Metodologi Penelitian dalam Bidang Kepariwisataan. Jakarta: PT Gramedia Pustaka

Mahagangga, dkk. 2015. Kajian Pengembangan Desa Wisata Badung. Dalam Seminar Nasional Sains dan Teknologi, Denpasar Bali.

Marcelina, S. W. 2018. Studi Daya Dukung Kawasan Wisata Dan Persepsi Wisatawan Di Pusat Latihan Gajah Way Kambas. Skripsi. Universitas Lampung.

Nugroho, S, dkk (ed). 2017. Tren Pariwisata Milenium: Diskursus dengan Alam, Bahasa, Sejarah, dan Pasar. Denpasar: Pustaka Larassan.

Pitana, I. G dan Gayatri. P. G. 2005. Sosiologi Pariwisata. Yogyakarta: Andi Ooffset

Soekanto, S. 2002. Sosiologi Suatu Pengantar. Jakarta: Rajawali Press.

Sudana, I. P. 2017. "Pariwisata Massa VS Pariwisata Alternatif" dalam Nugrooho, dkk (ed) Tren Pariwisata Milenium: Diskursus dengan Alam, Bahasa, Sejarah, dan Pasar. Denpasar: Pustaka Larasan.

Sugiyono.2008. "Metode Penelitian Kuantitatif Kualitatif dan $R \& D$ ". Bandung: Alfabeta.

Sunarta, I. N dan I. N. S. Arida. 2015. "Membangun Pariwisata dari Desa: Kearifan Loikal dalam Perencanaan dan Pengembangan Desa Wisata" dalam I Nyoman Sukma Arida dan Ni Ketut Arismayanti (ed.). Paradigma dan Kebijakan Pariwisata. Denpasar: Cakra Press

Suryasih, I. A. 2016. "Prinsip-Prinsip Pengembangan Produk Wisata Perdesaan" dalam I Putu Anom dan Ida Bagus Suryawan (ed.). Perkembangan dan Pengembangan Desa Wisata. Denpasar: Herya Media.

Suryawan, Ida Bagus., Suryasih, Ida Ayu., dkk. 2006. Perkembangan Pengembangan Desa Wisata. Bogor: Herya Widia.

TribunNews. 2019. Kemenpar Pasang Target 20 Juta Wisatawan Diakses melalui https://m.tribunnes.com/amp/bisnis/2019/kemenpa r-pasang-target $=20$-juta-wisatawan pada tanggal 12 nopember 2019 